\title{
The concept of "Passing" and Transgender Identity: An Analysis of Jackie Kay's Trumpet
}

\author{
Surinder Kaur \\ Department of English, S.G.A.D. Govt.College, Tarn Taran, Punjab.Email: sandhu.surinder85@gmail.com
}

\begin{abstract}
The concept of "Passing" dates back to eighteenth century meaning hiding one's race or sexuality and passing as the priviledged race or sexuality. Black individuals passed as white in the U.S in order to escape slavery. Hence to "pass" denotes an act of being something you are not in reality. Passing calls for an erasure of one's true self in the presence of others so "passing" is perceived as a performance. Today, the concept of passing is associated with transgender individuals. It is often reduced down to a "good/bad" dichotomy. Passing as cisgender can ensure safety, an escape from verbal and physical violence and it can reaffirm a transgender individual's identity. However, passing can be seen as deceptive or hiding on's true identity. Since passing signifies a performancee, some believe passing for transgender individuals simply means passing as man or woman. This supposition leads to the idea that "passing as cisgender" means a transgender creates a new identity for him/herself and establishes a new set of narratives- a conflicting set of narratives (one told and believed by trans person and another by medical system). The proposed endeavour attempts to analyze Jackie Kay's novel Trumpet (1998) as it exposes this conflicting set of "double narrative" of Joss Moody. The novel narrates the life and death of Joss, a trans man, who passes as a cisgender man until his death. Using Foucault's ideas about life and death, I aim to foreground the metaphorical killing of Joss by other persons in the novel. He is able to pass as man during his life but after his death when he can no longer control his body and medical system has access to his body and power over his body, punishes his identity by revealing its sex as female.
\end{abstract}

Keywords: Passing, Cisgender, Transgender, Conflict, Narrative, Identity

\section{INTRODCTION}

Human body has always been the subject of learned discussion. "Of all the objects in the world, the human body has a peculiar status: it is not only possessed by the person who has it, it also possesses and constitutes him ( Miller 1978: 14). Our bodies' behaviour is largely determined and regulated by the social and cultural rules. As Michael Foucault argues in The History of Sexuality that "our bodies are trained, shaped and impressed with the stamp of prevailing historical forms of selfhood, desire, masculinity and femininity" (1990:166). Bodies are controlled, supervised and continuously molded to fit within the constraints of heterosexuality. Gender is considered as the natural part of the body. Heterosexuality gives the binary of male or female and gender roles, masculine and feminine. A man is expected to display masculine features while a female is expected to be feminine. Bodies that do not fit or follow this heteronormative discourse are punished and suppressed. This puts enormous 
pressure on individuals with queer bodies such as transgender people to adopt the normal ways of life to appear and to be accepted as normal. That's why transgender people rarely disclose their real identities and pass as straight individuals from the fear of social outcasting. The concept of "Passing" dates back to eighteenth century then meaning hiding one's race or sexuality and passing as the priviledged race or sexuality. Black individuals passed as white in the U.S in order to escape slavery and later to escape discrimination and to get economic gain. Hence to "pass" denotes an act of being something you are not in reality. Passing calls for an erasure of one's true self in the presence of others so "passing" is perceived as a performance. Today, the concept of passing is associated with transgender individuals. It is often reduced down to a "good/bad" dichotomy. Passing as cisgender can ensure safety, an escape from verbal and physical violence and it can reaffirm a transgender individual's identity. However, passing can be seen as deceptive or hiding on's true identity. Since passing signifies a performancee, some believe passing for transgender individuals simply means passing as man or woman. This supposition leads to the idea that "passing as cisgender" means a transgender creates a new identity for him/herself and establishes a new set of narratives- a conflicting set of narratives (one told and believed by trans person and another by medical system). The proposed endeavour attempts to analyze Jackie Kay's novel Trumpet (1998) as it exposes this conflicting set of "double narrative" and 'multiplicity of selves' of the protagonist Joss Moody (King 2001:106-107). The novel narrates the life and death of Joss, a trans man, who passes as a cisgender man until his death. Using Foucault's ideas on life and death, I aim to foreground the metaphorical killing of Joss by other persons in the novel. So it is imperative to understand Foucault's key ideas regarding life and death before proceeding to analyze Joss's and medical community's conflicting narratives.

\section{MICHEL FOUCAULT'S “RIGHT OF DEATH AND POWER OVER LIFE”}

Michel Foucault is a major twenthieth century historian and critic whose ideas have shed illuminated light on the concepts of power, knowledge and order of things. His book History of Sexuality (1990) provides a detailed account of how bodies are supervised and controlled by social and cultural ethics in order to maintain supremacy of the dominant class. His essay, "Right of Death and Power Over Life" (1984) describes how the sovereign had the right to "take life or let live" instead of having power over life and death, as people normally believe (136). According to Foucault, the focus of modern world is "bio-power" i.e. to extend and improve life. Living bodies play an important role in this bio-power world. Foucault recounts that in classical period various institutions like universities, schools, barracks, workshops and political parties, discipline living bodies like to regulate bodies and punish the bodies that did not follow social rules of behaviour, "there was an explosion of numerous and diverse techniques for achieving the subjugation of bodies and the control of populations (1984:140). The people enforce the laws of these institutions, and therefore the people also maintain bio-power itself. Those who do not follow these rules can face death. Foucault states that the law and people who enforce the law impose certain norms: "Another consequence of this development of bio-power was the growing importance assumed by the action of the norm, at the expense of the juridical system of the law. Law cannot help but be armed, and its arm, par excellence, is death" (1984:144). Hence one must conform to normalcy or be punished to death. In heteronormative discourse, heterosexuality lays a claim on 'nature' and define itself as the unmarked natural form of sexuality while homosexuality is considered as unnatural and morbid. Heteronormativity, which can be defined as "the assumption that everybody is heterosexual and that the natural way of life is a heterosexual way of life. In research, the concept of heteronormativity refers to those institutions, structures, relations and actions that maintain 
heterosexuality as something homogeneous, natural and universal" (Rosenberg 2007:100). Coates says about heteronormativity that: "[it] is a term used by queer theorists to refer to a system in which heterosexual identities, relationships and practices are seen as the norm against which all sexuality is judged. Discourses of heteronormativity inevitably 'other' homosexuality and underpin homophobia"(2004:219). Hence heteronormative discourse further curtails the freedom of transgender and queer people. In contemporary world most important institutions of regulating bodies are medical and legal systems. Joss' body did not follow "the rules," according to medical and legal systems. He is able to pass as man during his life but after his death when he can no longer control his body and medical system has access to his body and power over his body, punishes his identity by revealing its sex as female. Hence Joss uses passing as his rescue during his life but medical community regulates his body after his death by declaring it as a female body.

\section{THE NOVEL: TRUMPET (1998)}

Praised as "starkly beautiful modern classic" and the winner of the Guardian fiction prize 1998, Jackie Kay's novel Trumpet is divided into two narrative sections, consisting of thirty-five chapters of variant length. The novel is set in Scotland at the end of the 1990s. Trumpet constructs the life and death of a trumpeter Joss Moody, a transgender man who successfully passes as a cisgender man until his death. The character of the Joss Moody is based on the jazz musician Billy Tipton. Exploring the life and death of Joss through the memories of Joss's wife Millie and his adopted son, Colman, the novel presents a detailed account of Joss's both private, intimate and public life. In an interview Kay said:

I was interested in how fluid identity can be, how people can reinvent themselves, how gender and race are categories that we try to fix, in order perhaps to cherish our own prejudices, how so called extraordinary people can live ordinary lives. I wanted to write a love story where the reader would become so involved with the story that they too would believe Joss and be calling him 'he' to themselves. (Bold Type, 1999)

Accordingly, the novel can be read as a critique of identity that disturbs the persistence of identity categories, not only that of gender and sexuality, but also of race and ethnicity, which are shown as unstable and intrinsically linked to other social categories (Kahkonen 2013:129)

Trumpet includes fluidity of an identity, a conflicting set of narratives; how Joss lived his life (as a man..the Joss story) and how Joss is identified after his death (as the sex he was declared at birth: female..the 'Josephine' story). While Millie, Colman, doctor's report, biographer's thoughts question Joss's way of living, his musician friends are the only ones who try "normalizing" or "rationalizing" Moody's life by praising his passion and love for music (Garber 1992:69; Halberstam 2005:55).

\section{MAINTAINING JOSS IDENTITY}

In Passing: Identity and Interpretation in Sexuality, Race, and Religion, Maria Sanchez and Linda Schlossberg suggest that passing "is not about erasure or denial, as it is often castigated but, rather, about the creation and establishment of an alternative set of narratives" (2001:4). In other words, Sanchez and Schlossberg do not believe passing should be seen as a disavowal of that person's past. Instead, passing should be considered as a way someone lives their life. In Trumpet, Joss is able to pass as a cis man until his death, which is an "alternative" narrative to the sex he was declared at birth and after death: female. One way Joss is able to pass is by avoiding medical treatment altogether. Throughout the novel, Millie and Colman recall memories of how Joss avoided doctors, but never explicitly 
saying or explaining why he did not want to see or visit doctors. Colman recounts, "My father had a lifelong terror, phobia whatever, about hospitals. Makes a lot of sense in hindsight. He was so scared of doctors, he passed that on to me" (68). Colman narrates when Joss got sick, he refused to get treatment. Joss would not see a doctor, even when his life depended on it. Since the medical community, both then and today, often pathologizes transgender individuals, Joss may not have been able to continue to live as a man. If the doctors had access to Joss' body during his life, someone could have leaked Joss' secret. Since Joss was a public figure, this revelation could have affected his career, his family, and his whole identity in a worse possible way. So Joss avoided the medical community and he was able to continue his identity as a man (his "alternative Joss" narrative) although he was declared female at birth.

\section{CLOTHING AND BANISHING FEMALE IDENTITY}

Clothing is one way to establish gender binaries. Both male and female has different set of clothes. Clothing helps Joss establish his identity to himself and to the world. Clothing also separates Joss from Josephine. Joss' male clothing and binding bandages are vital elements in Joss's passing as cisgender man because they hide his femininity and emphasize his masculine features. As Walker notes, "Without the individual, there is only a pile of clothes; the accessories that facilitate, but which do not constitute, the act of crossdressing: clothes may make the man, but only when they are worn" (2007:36). A person's gender is read from his clothes. Bonnet and skirts mean female while suits denote male. So in order to pass as man, Joss wears man clothes and bandage his breasts. Millie notes how "the bandages...were part of our life together" (203). The bandages not only hide his breasts from the rest of the world, but they also hide his breasts from Millie and from himself. Concealing and ignoring his "female" body help Joss form his new identity as a man. No one has access to his unclothed body except Millie when he is living. After his death, many people have access to his body-doctors, the funeral director, Colman-without Joss' permission. Colman is devastated by this discovery. He was bewildered because he has seen his father wearing masculine attire but now he sees a female body during the funeral. Colman thinks, "It was the weirdest thing, but the man in the coffin and the woman that I saw in that funeral parlour really did seem to me to be two different people" (72). Even Colman (whether it is because he wants to see his father as a man or other reasons) recognizes that the clothing changes the person and allows them to pass as cisgender. Clothing is much more than a performance for Joss. It becomes a code to be read as a man in the world.

\section{PAST AND PRESENT}

Passing is often understood as a complete erasure of a trans individual's past life. Joss only distances himself from his past (Josephine) and never completely erases his past and relationships. Instead of destroying his "letters, photographs, records, documents, certificates" (276), Joss chooses to leave the archive of his life to Colman. He writes to Colman that he is "all set to destroy all of this. Burn the lot. I stopped myself. If I do that I'd literally be burning myself. I couldn't do that to myself, to my music. But most of all, I couldn't do it to you....I'm leaving myself to you" (276-77). After Joss' death, Maggie the maid tells Colman that she saw a letter in Joss' desk. Maggie says, "My eye caught a letter... It began, 'Dear Mum,' which was odd since Mr. Moody told me his mother had died a long time ago... But the strangest thing was how the letter was signed. It was signed Josephine" (178). Joss writes a letter to his mother and signs it as Josephine. Maggie, the maid accidently discovering the letter, thinks that Joss wrote it for someone else. Joss maintains a distance from his past. Present 
people only know of Joss while people from past know of only Josephine. Letters and certificates are the only connection between Joss and Josephine. Alive, Joss defends his "alternative Joss narrative" but his death brings back Josephine narrative. However Joss's refusal to destroy his history challenges the notion that trans people necessarily want to erase their pasts. His assertion that burning these papers would do violence not only to himself but also to his son highlights the interconnection of their identities. By passing his personal history onto Colman, Joss resists the silencing of his past that he has experienced all his life. (Koolen 2010: 8).

\section{JOSS OR JOSEPHINE: UNVEILING OF THE TRUTH}

Joss did not follow "the body rules," according to medical and legal systems. He is able to pass as cis man during his life, so his body is not punished. However after death, Joss's identity is punished. In terms of Joss' story, the current system of bio-power is a combination of the "ancient system" and the bio-power system that Foucault identifies. The institutions mentioned earlier (schools, hospitals, and other places discipline bodies meant for bio-power purposes) have the power to punish and even to kill, literally and figuratively (and these institutions replace the sovereign and their power). In the novel, the sovereign is replaced by medical community. Doctor must reflect "the law" of the medical institution. This law is shown here: Joss, a person with breasts and a vagina, must be declared "woman." After the doctor examined Joss' body, she "got her red pen out from her doctor's bag. What she thought of as her emergency red pen. She crossed out 'male' and wrote 'female' in her rather bad doctor's handwriting" (44). As Foucault says, the law "has to qualify, measure, appraise, and hierarchize, rather than display itself in its murderous splendor" (1984:144). In this example, the doctor measures and appraises Joss, and determines that he is "breaking the law" because Joss lived as a man but has culturally defined female genitalia. Measurements and "facts" (which contribute to the "Josephine" narrative) disguise the actual violence that this doctor is doing to Joss' identity (the "Joss" narrative". With her vivid, permanent red pen, she crosses out how Joss lived-metaphorically killing the "Joss" narrative-and rewrites his whole life as if he lived as a woman. The law must be upheld. The medical community in this novel has tremendous power to extend or extinguish life and certain ways of living or erasing the identity of someone who passes as cisgender. In other words, the person named "Joss" is killed as soon as the medical community inspects his body-Joss is no longer himself after he dies. The people who obey the law are the ones whose lives and identities are extended in life and in death while others are completely eliminated.

\section{JOSS AND FAMILY STIGMA}

The actions of binding his breasts and presenting himself as a man, enables Joss to pass as cisgender during his life without the stigma of having an abnormal identity. Joss is able to actively defend and perform his masculinity every day. As Erving Goffman states, "Where the stigma is nicely invisible and known only to the person who possesses it, who tells no one, then here again is a matter of concern in the study of passing" (1963:73). A person may be stigmatized because of their character traits, including mental disorder, physical stigma, and stigma of group identity. A person with an invisible stigma, as Goffman emphasizes in the quote above, can pass as "normal" (cisgender, in Joss' case) and can live without the labels of "bad" or "abnormal." In life, Joss has control over his own masculinity, and therefore has some sort of agency but in his death, Joss loses his agency, and is stigmatized by others, Goffman writes, "The tendency for a stigma to spread from the stigmatized individual to his close connections provides a reason why such relations tend to either be avoided or to be terminated, where existing" (1963:30). However, Millie and Colman, who could terminate or 
disavow their relationship with Joss now that he is dead, find themselves holding on to him in the end, which results in their own stigma. Joss' identity is "punished" after his death, Millie and Colman are punished during their lives. The media labels Millie as "lesbian." She hides from the flashes of photographers and from the reporters: "[Millie] never imagined that people could make such a fuss. [She] know[s] now why they call reporters hounds. [She] feel[s] hounded, hunted. Pity the fox" (5). Though Millie stays mum to reporters, she is embarrassed by this lesbian label, "Lesbian" is a term that could hurt Millie because of the stigma attached to it. The stigma, though, may have to do more with Joss' identity. If Joss was not a man, then it seems their whole relationship - as husband and wife-was a lie. Therefore, when Joss' gender identity is challenged, Millie's sexual identity is also challenged. Millie says, "... what hurts me the most is the fact that I am still alive. If it were not for Colman, I would not be sitting here feeling this strange sharp pain of the living” (Davies 2006:36). Joss' stigma affects Colman in different ways than it affects Millie. The novel implies that Colman's masculinity is damaged after Joss' death. Mandy Koolen argues that Colman has "(sub)consciously modelled his masculinity on his memory of this father" (2010:77). Colman says: "When I was little, I could coast, bask in his glory. 'Joss Moody's son' It was all right, it was, being Joss Moody's son" (45). But now, it is embrassing: "Colman Moody, son of Joss Moody, the famous trumpet player. You know the one. The one who pretended to be a man and fetched up a woman at his death. Conned his own son. That boy must have been thick" (46). Part of Colman's processing is how his own masculinity is in question because of his father's "female" masculinity leads him to tell "the truth" about his father to biographer and this hurts both him and his father.

\section{CONCLUSION}

In Passing: Identity and Interpretation in Sexuality, Race, and Religion, Maria Sanchez and Linda Schlossberg suggest that passing "is not about erasure or denial, as it is often castigated but, rather, about the creation and establishment of an alternative set of narratives" (2001:4). In other words, Sanchez and Schlossberg do not believe passing should be seen as a disavowal of that person's past. Instead, passing should be considered as a way someone lives their life. Joss uses passing to create his new identity, his set of narrative but the regulating power, which values law as the uppermost thing, destroys Joss narrative. Medical community does not value emotions of a human being. It only reads bodies as male or female. Joss does not want to be labeled as abnormal as society normally does with trans individuals and castigates them because they are different. Trumpet clearly gives the message that our existence is simply not a matter of fitting in the male/female, masculine/feminine binary, but a matter of an expression of inner personality, our inner self, of who we really are. In our myopic vision of upholding the hypocritical social and cultural codes of behaviour, we are robbing trans individuals of their opportunities to live freely and flourish as humans. We must read and value an individual based on his/her capabilities, potential and his/her contribution to the upliftment of the society. 


\section{REFERENCES}

\section{Primary sources}

Kay, Jackie. Trumpet. New York: Pantheon, 1998. Print.

\section{Secondary sources}

Coates, Jennifer, Women, Men and Language: A sociolinguistic Account of Gender Differences in Language, Harlow, Pearson Education Limited, 2004, pp. 213-221.

Davies, Ceri. “'The Truth is a Thorny Issue’: Lesbian Denial in Jackie Kay's Trumpet.” Journal of International Women's Studies 7.3 (2006): 5-16. Print.

Foucault, Michel. "Right of Death and Power over Life." The Foucault Reader. Ed. Paul Rabinow. New York: Random House, 1984. Print.

Foucault, Michel. The History of Sexuality, Vol. 1: An Introduction. Vintage. 1990. Print.

Garber, Marjorie.. Vested Interests: Cross-Dressing and Cultural Anxiety. New York: Harper-Perennial. 1992. Print.

Goffman, Erving. Stigma; Notes on the Management of Spoiled Identity. Englewood Cliffs, NJ: Prentice-Hall, 1963. Print.

Halberstam, J. Jack. “Unlosing Brandon: Brandon Teena, Billy Tipton, and Transgender Biography.” In A Queer Time and Place: Transgender Bodies, Subcultural Lives. New York: New York UP, 2005. 47-75.

Kahkonen, Lotta, " Reading the Potential of Jackie Kay's Trumpet for Transgender Ethics” in Lambda Nordica $3-4 / 2013$ retrieved on 28-12-2016 from

http://www.lambdanordica.com

King, Jeannette, “A Woman's a Man, for a 'That': Jackie Kay's Trumpet”, in Scottish

Studies Review, Vol. 2, 2001, pp. 101-109.

Koolen, Mandy. "Masculine Trans-formations in Jackie Kay's Trumpet." Atlantis: Critical Studies in Gender, Culture \& Social Justice 35.1 (2010) 71-80

Miller, Jonathan. The Body in Question New York: Random House. 1978. Print.

Rosenberg, Jordana, “'Serious Innovation': A Conversation with Judith Butler”, in A Companion to Lesbian, Gay, Bisexual, Transgender and Queer Studies, editors George E. Haggerty and Molly McGarry, Oxford, Blackwell. 2007. Print. pp. 379-388.

Sanchez, Maria, and Linda Schlossberg, eds. Passing: Identity and Interpretation in Sexuality, Race, and Religion. New York: New York UP, 2001. Print.

Walker, Alice. “As You Wear: Cross-dressing and Identity Politics in Jackie Kay's Trumpet." Journal of International Women's Studies, 8.2 (2007): 35-43. Print.

\section{Interviews}

Bold Type. "An Interview with Jackie Kay". Volume 3.1 Therapy April. (accessed 12-1-2017) 1999. Retrieved from http://www.randomhouse.com/boldtype/0499/kay/interview.html 